\title{
Vitamin D status is negatively correlated with retinal nerve fiber layer thickness in relapsing-remitting MS patients without acute optic neuritis
}

Citation for published version (APA):

Knippenberg, S., Smolders, J., van den Maegdenbergh, M., Porro, G., Damoiseaux, J., \& Hupperts, R. (2017). Vitamin D status is negatively correlated with retinal nerve fiber layer thickness in relapsingremitting MS patients without acute optic neuritis. Multiple Sclerosis Journal, 23(1), 128-129. https://doi.org/10.1177/1352458516652950

Document status and date:

Published: 01/01/2017

DOI:

10.1177/1352458516652950

Document Version:

Publisher's PDF, also known as Version of record

Document license:

Taverne

Please check the document version of this publication:

- A submitted manuscript is the version of the article upon submission and before peer-review. There can be important differences between the submitted version and the official published version of record.

People interested in the research are advised to contact the author for the final version of the publication, or visit the DOI to the publisher's website.

- The final author version and the galley proof are versions of the publication after peer review.

- The final published version features the final layout of the paper including the volume, issue and page numbers.

Link to publication

\footnotetext{
General rights rights.

- You may freely distribute the URL identifying the publication in the public portal. please follow below link for the End User Agreement:

www.umlib.nl/taverne-license

Take down policy

If you believe that this document breaches copyright please contact us at:

repository@maastrichtuniversity.nl

providing details and we will investigate your claim.
}

Copyright and moral rights for the publications made accessible in the public portal are retained by the authors and/or other copyright owners and it is a condition of accessing publications that users recognise and abide by the legal requirements associated with these

- Users may download and print one copy of any publication from the public portal for the purpose of private study or research.

- You may not further distribute the material or use it for any profit-making activity or commercial gain

If the publication is distributed under the terms of Article $25 \mathrm{fa}$ of the Dutch Copyright Act, indicated by the "Taverne" license above, 


\section{Letters}

Vitamin D status is negatively correlated with retinal nerve fiber layer thickness in relapsing-remitting MS patients without acute optic neuritis

Date received: 26 April 2016; accepted: 8 May 2016

In this journal, Burton et al. demonstrated a correlation of vitamin D insufficiency with greater thickness of the retinal nerve fiber layer (RNFL) as measured with optical coherence tomography (OCT) in patients with acute optic neuritis (ON). The authors conclude that an elevated RNFL thickness in acute $\mathrm{ON}$ may reflect a greater propensity for inflammation in the setting of vitamin D insufficiency. ${ }^{1}$ We would like to further elaborate on this interpretation.
We collected a cohort of 27 relapsing-remitting multiple sclerosis (RRMS) patients without clinically active disease activity, in which OCT recordings (Stratus 3 OCT; Carl Zeiss B.V, Sliedrecht, the Netherlands), pattern visual evoked potential (VEP) recordings, visual acuity measurements (Snellen chart), and 25-hydroxyvitamin D measurements (Chemiluminescence assay; Immunodiagnostic Systems, Liège, Belgium) were performed during 12-month follow-up. This cohort consisted of 3 men and 24 women, mean age was 38.6 years (standard deviation $(\mathrm{SD})=11.4$ years $)$, median disease duration since diagnosis was 1.0year (interquartile range $(\mathrm{IQR})=0.17-2.13$ years $)$, and median baseline Expanded Disability Status Scale (EDSS) score was $1.0(\mathrm{IQR}=1.0-1.5)$. A total of 11 subjects were treated with glatiramer acetate, the remainder was untreated.
Multiple Sclerosis Journal 2017, Vol. 23(1) 128-129 DOI: $10.1177 /$ 1352458516652950

(C) The Author(s), 2016. Reprints and permissions: http://www.sagepub.co.uk/ journalsPermissions.nav
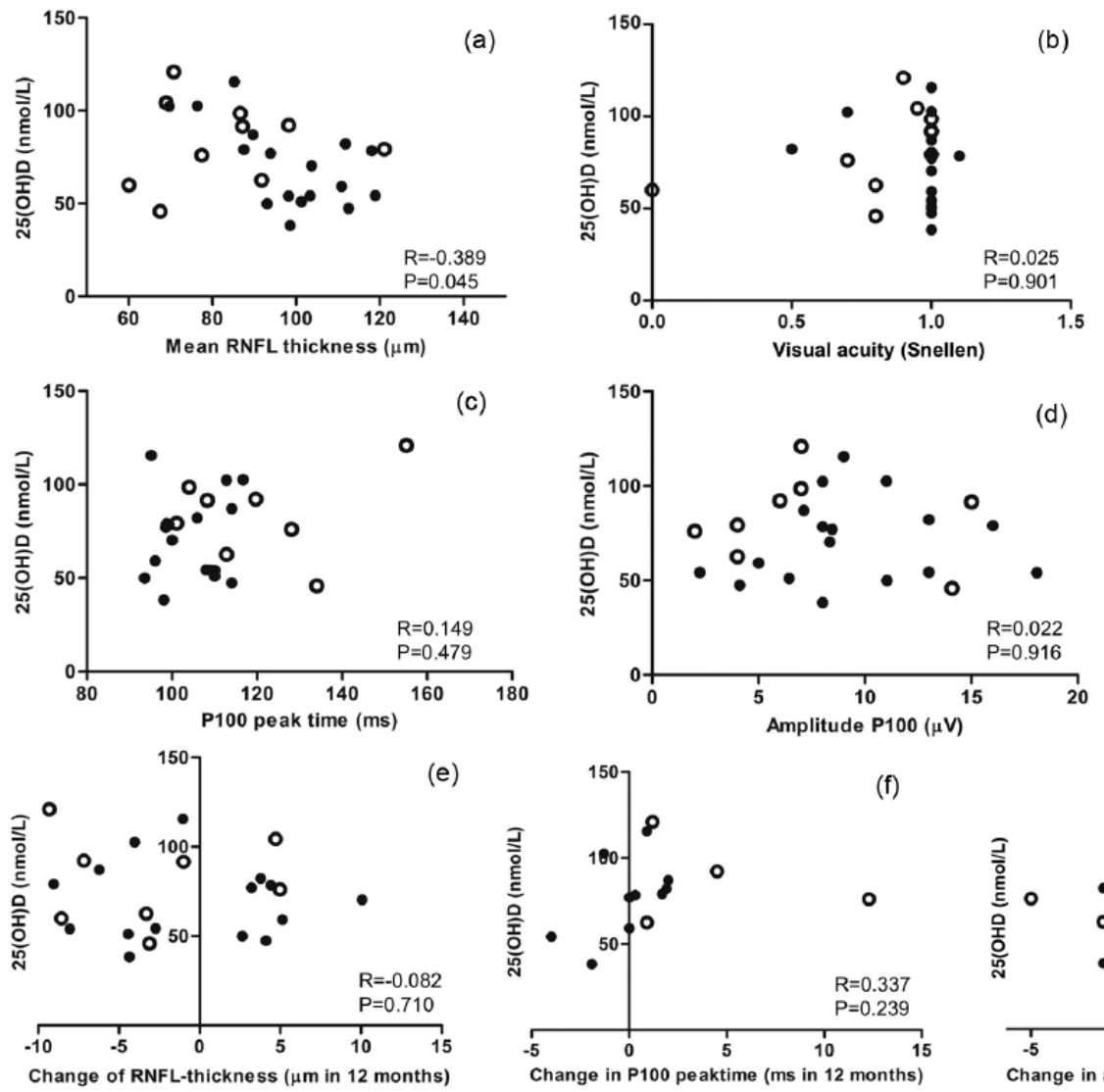

(e)
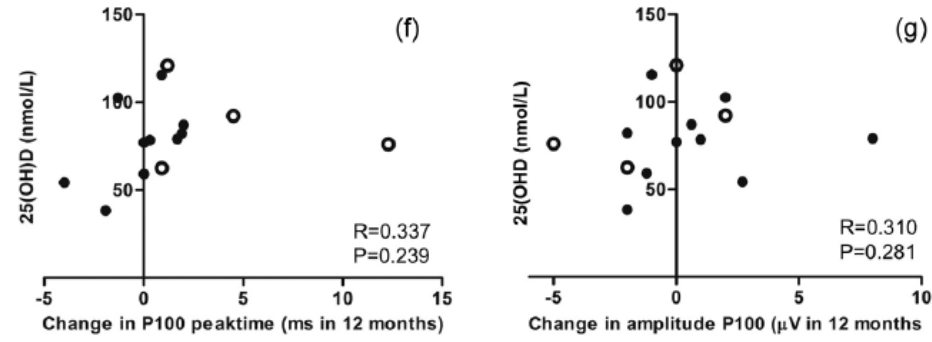

Figure 1. Correlation between vitamin D status and OCT, visual acuity, and VEP outcomes. Correlation of vitamin D status with (a) RNFL thickness, (b) visual acuity, (c) VEP P100 latency, (d) VEP amplitude, (e) change of RNFL thickness, (f) change in VEP P100 latency, (g) change in VEP amplitude. Open dots represent patients with prior ON, and closed dots represent patients without prior $\mathrm{ON}$. 
A total of 10 subjects had a history of ON. Patient characteristics were not significantly different between MS subjects with ON or without ON. The worst performing eye was included in the analysis.

Like Burton et al., we observed a negative correlation between vitamin D status and RNFL thickness at baseline (Figure 1(a)). This correlation was stronger when only subjects without previous $\mathrm{ON}$ were analyzed $(r=-0.601, p=0.011)$. We investigated other outcomes of optic nerve function. Vitamin D status did not correlate with visual acuity, VEP P100 latency, or VEP amplitude (Figure 1(b)-(d), respectively). Stratification for a history of ON did not affect the results (data not shown). Finally, we assessed the correlation between vitamin $\mathrm{D}$ status at baseline and the 12-month change of RNFL thickness, VEP P100 latency, and VEP amplitude. We found no correlation between vitamin D status and change of RNFL thickness, change of VEP P100 latency, and change of VEP amplitude (Figure 1(e)-(g), respectively).

Although the negative correlation between $25(\mathrm{OH}) \mathrm{D}$ levels and RNFL thickness reported by Burton et al. was hypothesized to be due to inflammation of the optic nerve, we replicated this finding in a cohort without active ON. Therefore, an effect of inflammation is unlikely. Alternatively, a detrimental effect of $25(\mathrm{OH}) \mathrm{D}$ on RNFL thickness could be hypothesized but is not supported by the longitudinal data of Burton et al., and by the longitudinal OCT and VEP data in this letter. Providing alternative explanations is challenging. A higher ultraviolet (UV) exposure has been associated with a higher risk of macular degeneration. ${ }^{2}$ Therefore, the lower vitamin D status in patients with a reduced RNFL thickness could be a biomarker for detrimental effects of UV-light exposure on the retina. Nevertheless, although the interpretation of the correlation between vitamin D status and RNFL thickness is uncertain, the beneficial effect of vitamin D status on $\mathrm{ON}$ recovery demonstrated by Burton et al. is exciting and warrants further investigation.

\section{Declaration of Conflicting Interests}

The author(s) declared no potential conflicts of interest with respect to the research, authorship, and/or publication of this article.

Response to "Vitamin D status is negatively correlated with retinal nerve fiber layer thickness in relapsing-remitting MS patients without acute optic neuritis" by Knippenberg et al.

Date received: 7 May 2016; accepted: 9 May 2016
Funding

The author(s) disclosed receipt of the following financial support for the research, authorship, and/or publication of this article: This project was sponsored by an unrestricted grant by TEVA.

\section{References}

1. Burton JM, Eliasziw M, Trufyn J, et al. A prospective cohort study of vitamin D in optic neuritis recovery. Mult Scler. Epub ahead of print 1 April 2016. DOI: $10.1177 / 1352458516642315$.

2. Schick T, Ersoy L, Lechanteur YT, et al. History of sunlight exposure is a risk factor for age-related macular degeneration. Retina 2016; 36(4): 787-790.

\section{Stephanie Knippenberg1,2,3, Joost Smolders ${ }^{1,4}$, Marianne van den Maegdenbergh ${ }^{5}$, Giorgio Porro ${ }^{6}$, Jan Damoiseaux ${ }^{7}$ and Raymond Hupperts ${ }^{1,2}$}

${ }^{1}$ Academic MS Center Limburg, Department of Neurology, Zuyderland Medical Center, Sittard, The Netherlands

${ }^{2}$ School for Mental Health and Neuroscience, Maastricht University Medical Center, Maastricht, the Netherlands

${ }^{3}$ Department of Neurology, Zuyderland Medical

Center, Heerlen, The Netherlands

${ }^{4}$ Department of Neurology, Canisius Wilhelmina

Hospital, Nijmegen, The Netherlands

${ }^{5}$ Department of ophthalmology, Zuyderland

-Eyescan, Sittard, the Netherlands

${ }^{6}$ Department of ophthalmology, Amphia Hospital,

Breda, the Netherlands

${ }^{7}$ Central diagnostic laboratory, Maastricht

University Medical Center, Maastricht, The

Netherlands

Correspondence to:

$S$ Knippenberg

Department of Neurology, Zuyderland Medical

Center, Henri Dunantstraat 5, 6419 PC Heerlen,

The Netherlands.

\section{S.Knippenberg@maastrichtuniversity.nl}

Dear Multiple Sclerosis Journal Editors and Dr Knippenberg and colleagues,

Thank you to Dr Knippenberg and colleagues for your letter. ${ }^{1}$ Dr Knippenberg et al. report that in their study of 27 patients with relapsing-remitting multiple
Visit SAGE journals online http://msj.sagepub.com

@ SAGE journals

Multiple Sclerosis Journal 2017, Vol. 23(1) 129-130 DOI: 10.1177 1352458516652951

(C) The Author(s), 2016. Reprints and permissions: http://www.sagepub.co.uk/ journalsPermissions.nav 